\title{
Evaluation of the basal area growth models in the Finnish stand simulator MOTTI with data from the Estonian network of permanent forest growth plots
}

\author{
Ando Lilleleht ${ }^{{ }^{*}}$, Allan Sims ${ }^{1}$, Andres Kiviste ${ }^{1}$, Jari Hynynen ${ }^{2}$ and \\ Mika Lehtonen ${ }^{2}$
}

Lilleleht, A., Sims, A., Kiviste, A., Hynynen, J., Lehtonen, M. 2011. Evaluation of the basal area growth models in the Finnish stand simulator MOTTI with data from the Estonian network of permanent forest growth plots. - Forestry Studies | Metsanduslikud Uurimused 55, 80-97. ISSN 1406-9954.

\begin{abstract}
Forest management has become a more complex issue than it has ever been before. Foresters need to fulfill the demands of several interest groups, often which are conflicting. Finding the balance between different management objectives can be facilitated with the use of decision support systems. Since no decision support systems have been developed in Estonia, the aim of this study is to assess the applicability of the Finnish stand growth simulator MOTTI in Estonia. The evaluation focuses on the basal area growth models; the data used originates from the Estonian network of permanent forest growth plots. Tree-level bias models were constructed for all major tree species in order to assess model performance. Also, bias was examined visually with the use of residual plots. Results show that bias levels and variables which contribute to bias differ by species. Based on the fit statistics of the bias models, Common aspen shows the highest bias level whereas the growth of Gray alder seems to be predicted most accurately. Although model performance is decent for a model that is used outside of its application limits, calibration should still be considered as a prerequisite to implement the MOTTI system in Estonian forestry practice.
\end{abstract}

Keywords: model evaluation, analysis of residual, stand simulator, permanent plots, basal area growth.

Authors' addresses: ${ }^{1}$ Department of Forest Management, Institute of Forestry and Rural Engineering, Estonian University of Life Sciences, Kreutzwaldi 5, 51014 Tartu, Estonia; ${ }^{2}$ Finnish Forest Research Institute, Vantaa Research Centre, Box 18, Fin-01301 Vantaa, Finland, *e-mail: ando.lilleleht@emu.ee

\section{Introduction}

Forests serve a multitude of purposes and address many different, often conflicting, goals to satisfy the needs of forest owners, forest industry, and society at large. This poses considerable challenges to forest managers. The need for enhanced forest decision support systems (DSSs) is evident in several EU documents related to the future role of European forests. DSS is a system, which helps to simulate different scenarios to provide an overview and results from forest data with user selected options and thus helps to make decision. Forest DSSs allow the forest manager to use advanced decision support tools, such as expert and knowledge based systems, multi-criteria techniques as well as communication and visualization tools.

Many DSSs are created and an overview is available on the homepage of COST Action FP0804 (http://fp0804.emu.ee/wiki), where more than 60 DSSs are described. 
However, those are developed for different purposes and for usage in different parts of the world. For using those in Estonian forest practice, it is needed at first to validate and if necessary to calibrate on Estonian forest data.

A number of growth and yield tables have been developed by many authors in Estonia:

- for Scots pine (Pinus sylvestris L.) - Reim (1930), Muiste (1959), Gräzin (Krigul, 1969), Kasesalu (1969), Kiviste (Tappo, 1982);

- for Norway spruce (Picea abies L.) Gräzin (Krigul, 1969), Kiviste (Tappo, 1982);

- for Silver birch (Betula pendula Roth.) - Henno (1959; 1965), Kiviste (Tappo, 1982);

- for black alder (Alnus glutinosa L.) Haller (1932).

As empirical models, several stand growth models (Tappo, 1982; Kiviste, 1999a,b; Nilson, 2005) and some singletree models (Jõgiste, 1998) have also been developed for stand growth prediction in Estonia. Only few authors have developed process-based forest models (Kull \& Kull, 1989; Oja \& Arp, 1997) in Estonia.

The algebraic difference equations by Kiviste (1999a,b) are being employed as general growth and yield prediction functions in practical forest management planning in Estonia. These models were developed with the base-age invariant approach described by Cieszewski and Bella (1989). The model parameters were estimated using the data of the state forest inventory in Estonia in 1984-1993 (Kiviste, 1995, 1997).

The main reason for modest adaptation of growth models is not the lack of knowledge on forest growth and yield but the absence of a user-friendly system that would link the models into a single toolbox of equations. Therefore, the need for stand simulation software that could be used intuitively in decision support is unfilled. End-users demand a program that would allow custom management scenarios and incorporate a set of accurate growth and mortality models for reliable forecasting of future yields.

In assessing alternative methods for introducing modern decision support systems in Estonia, adaptation of existing systems is one option to be considered. In Northern Europe, there is quite a long tradition in applying model-based systems to support decision making at varying levels of forest management planning. Mela-system (Siitonen, 1993) in Finland, and HUGINsystem (Hägglund, 1981; Söderberg, 1986) in Sweden, are examples of the first comprehensive systems which were widely applied in practice. Since then, several simulation and optimization tools have been developed in Northern countries.

In Finland, a lot of research and development effort has been put in development of MOTTI stand simulator. It is designed to serve as an analysis tool and decision support system in assessing the impacts of forest management on stand dynamics, growth and yield, and profitability of forest management (Hynynen et al., 2005; Salminen et al., 2005). MOTTI has been developed to be applicable for all the major tree species and sites throughout Finland.

In MOTTI, stand dynamics is predicted with a set of stand-level and individual-tree growth and yield models (Hynynen et al., 2002). Natural regeneration and early development is predicted with stand-level models together with size distribution models. Growth of trees after stand canopy closure is predicted with distance-independent models for tree basal area and height growth. In the prediction of natural mortality, both individual-tree survival models, and stand-level self-thinning models are applied (Hynynen, 1993; Hynynen et al., 2002).

In the development of growth models of MOTTI, data from designed growth and yield experiments as well as Finnish 
National Forest Inventory growth plots have been used (Hynynen et al., 2002). Individualtree basal area and height growth models were fitted to extensive, permanent sample plot data of INKA (inventory growth plots) and TINKA (young forest inventory growth plots) (Gustavsen et al., 1988; Hynynen et al., 2002). These data form subsamples of stands, containing sample-plot data of the sixth and seventh Finnish National Forest Inventories. Before applying the models in simulation, they were tested and calibrated using the temporary sample plot data of the eighth National Forest Inventory, which is a representative sample of Finnish forests. Validation and calibration were needed in order to obtain growth predictions for tree species and sites which were absent or poorly represented in the fitting data. Another purpose of the calibration was to ensure that predicted growth level is in line with measured growth level of National Forest Inventory plots. The validation and calibration process is described in detail in Hynynen et al. (2002).

Although the growth and yield models of MOTTI are developed for Finnish conditions, they may be applicable also to Estonian growth conditions after calibrating with local data using similar kind of validation and calibration procedure as described above. Many of the growth conditions are close to each other in Estonia and Finland. There are no major differences in climate and tree species. Also, to some degree site types are similar, although due to historical reasons the classification of sites and calculation of stand variables is different.

The main aim of this study was to assess the applicability of MOTTI in Estonia by comparing the predicted individual tree basal area growths against Estonian permanent forest growth plots data. Also, we analyzed and evaluated the performance of growth models with respect to key variables describing tree and stand characteristics.

\section{Material and Methods}

\section{Data set}

The data used for evaluating the models comes from the Estonian network of permanent forest growth plots (Fig. 1). The network was established to provide data for developing individual-tree growth models for Estonia. The plots are usually re-measured every fifth year, the oldest data dates back to 1995 when the first plots were measured. The plots are established using a methodology similar to Gustavsen et al. (1988). The main criteria for plot selection were comprehensive coverage of main tree species, site types, age classes and stand densities. The majority of plots are located in state owned managed forest stands. To ensure that the models can be used throughout the country, the original target number of plots was approximately 600 . Usually, the plots are laid out in random groups, but where possible, are joined with the plots of NFI (Eesti metsade statistilise..., 2000) or ICP FOREST 1 (Karoles et al., 2000). The plots are circular and have a radius ranging from 15 to 30 meters in steps of 5 meters. The plot size depends on the number of trees on the plot; the minimum number should be at least 100 trees per plot. For each tree polar coordinates (distance from plot centre and azimuth), tree species, canopy layer, diameter at breast height $(1.3 \mathrm{~m})$ in two directions and defects are recorded. Every fifth tree is selected as a sample tree and its height and crown length are additionally measured. Also, the geographical coordinates of the plot are recorded with a handheld GPS device when establishing new plots. The plot network is described in detail by Kiviste and Hordo (2002).

A subset of the data from the network of permanent plots was created for the evaluation (Table 1). Only plots on mineral soils were used since MOTTI uses separate models for growth on peatlands. Both pure and mixed stands were selected; no limits for stand origin, age or density were set. In the analysis, only trees from the upper storey (current or future crop trees) were used. 


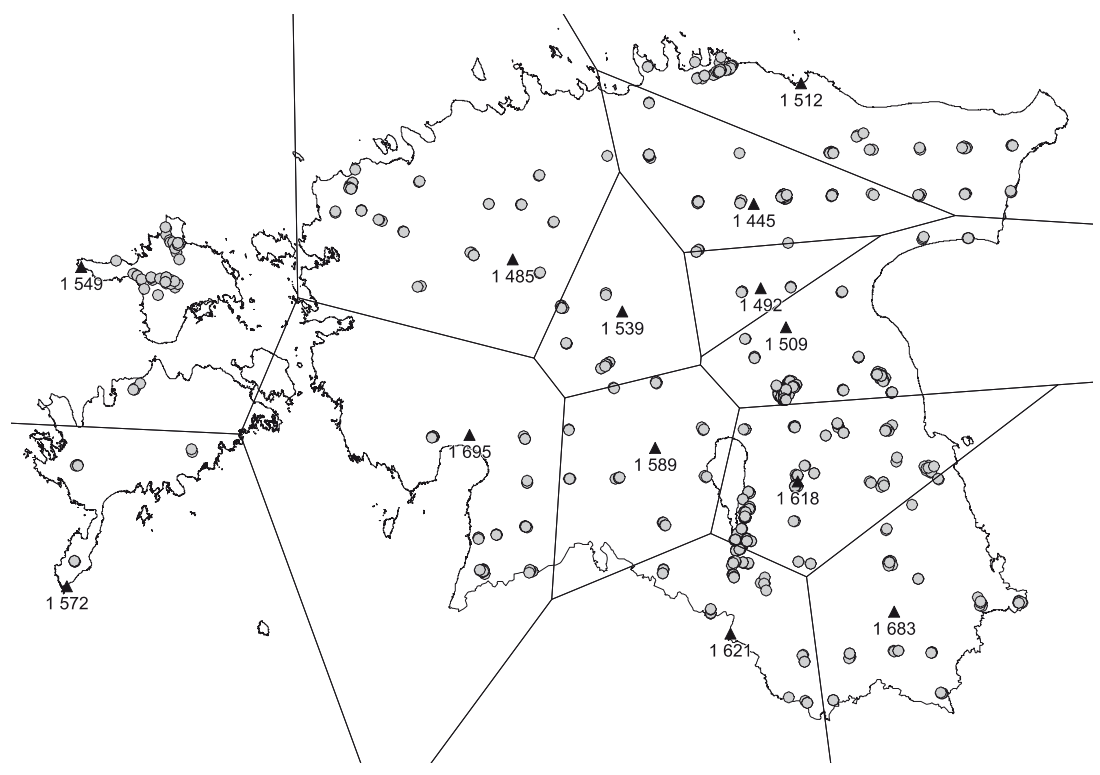

Figure 1. The Estonian network of permanent forest growth plots with temperature sum regions. Triangles show weather stations and their mean annual temperature sum (threshold $+5^{\circ} \mathrm{C}$ ) for period $1995-2007$ in each region. Regions were created as Voronoi polygons. Grey circles are forest growth plots.

Joonis 1. Eesti metsa kasvukäigu püsiproovitükkide võrgustik koos temperatuuride summade regioonidega. Kolmnurgad tähistavad mõõtmisjaamu, nende all on vastava piirkonna aastakeskmine aktiivsete ööpäevakeskmiste õhutemperatuuride summa (piirväärtus $+5^{\circ} \mathrm{C}$ ) ajavahemikul 1995-2007. Regioonideks jaotamine teostati Voronoi polügoone kasutades. Hallid ringid tähistavad proovitükke.

\section{Evaluation methods}

The evaluation of the models is mainly a problem of transferability since the key difference of the datasets used for model construction and evaluation is their geographic origin. In order to evaluate the models, single-tree measurement data from permanent plots was converted to a format compatible with MOTTI. A modified version of MOTTI software was used that allows batch input of spreadsheet data; no other changes to the program, including model structure were made. The program requires two separate input files, one containing stand-level data and another that consists of tree-level data. The stand file contains information about main tree species, stand origin, site fertility class, thickness of the organic soil layer, thinnings during the last five years and additional characteristics like sea and lake indices (propor- tional coverage of sea/lakes within a radius of $20 \mathrm{~km}$ ). The fertility classes (Table 1), corresponding to those by Kuusela and Salminen (1969), were derived from the site types as described by Lõhmus (2006) that are used in Estonia. Mean annual effective temperature sum, which is the main variable responsible for describing climatic variation, was not included in the input file but was set at a fixed amount (1327 ddy) for all plots. The tree-level input data consists of species code, age, diameter at breast height, height and height of crown base (if measured). Since tree heights are measured only for the sample trees, the heights for tally trees were calculated with the heightdiameter equations developed by Kiviste et al. (2003).

After calculating the 5-year growths with MOTTI software, the predicted individual-tree diameters from the output file 
Table 1. Site types (Lõhmus, 2006), their abbreviations (ST) and corresponding fertility classes (Kuusela \& Salminen, 1969). Number of observations (tree basal area increments) is given by site types and tree species.

Tabel 1. Kasvukohatüübid (Lõhmus 2006), nende lühendid (ST) ning rühmitamine viljakusklassidesse (Kuusela \& Salminen, 1969). Vaatluste arv (puude rinnaspindalade juurdekasvud) on antud kasvukohatüüpide ja puuliikide lõikes.

\begin{tabular}{|c|c|c|c|c|c|c|c|c|}
\hline \multirow[b]{2}{*}{$\begin{array}{l}\text { Site type } \\
\text { Kasvukohatüüp }\end{array}$} & \multirow[b]{2}{*}{$\begin{array}{l}\text { ST } \\
\text { ST }\end{array}$} & \multirow{2}{*}{$\begin{array}{c}\text { Fertility } \\
\text { class } \\
\text { Viljakus- } \\
\text { klass } \\
\end{array}$} & \multicolumn{6}{|c|}{ Tree species / Puuliik } \\
\hline & & & $\begin{array}{c}\text { Scots } \\
\text { pine } \\
\text { Harilik mänd }\end{array}$ & $\begin{array}{c}\text { Norway } \\
\text { spruce } \\
\text { Harilik kuusk }\end{array}$ & $\begin{array}{l}\text { Silver } \\
\text { birch } \\
\text { Arukask }\end{array}$ & $\begin{array}{c}\text { Common } \\
\text { aspen } \\
\text { Harilik haab }\end{array}$ & $\begin{array}{l}\text { Common } \\
\text { alder } \\
\text { Sanglepp }\end{array}$ & $\begin{array}{c}\text { Gray } \\
\text { alder } \\
\text { Hall lepp }\end{array}$ \\
\hline Filipendula & AN & 3 & 249 & 2795 & 3695 & 358 & 954 & 368 \\
\hline Oxalis & JK & 2 & 1955 & 7492 & 1181 & 72 & 86 & 79 \\
\hline Oxalis-Myrtillus & JM & 2 & 2067 & 2470 & 1542 & 457 & 68 & 89 \\
\hline Oxalis-Rhodococcum & $J P$ & 3 & 6805 & 930 & 387 & 30 & 0 & 0 \\
\hline Calamagrostis-alvar & $\mathrm{KL}$ & 5 & 684 & 86 & 77 & 0 & 0 & 0 \\
\hline Polytrichum-Myrtillus & KM & 4 & 1549 & 104 & 258 & 32 & 191 & 0 \\
\hline Calluna & $\mathrm{KN}$ & 5 & 2495 & 27 & 83 & 0 & 0 & 0 \\
\hline Polytrichum & $\mathrm{KR}$ & 4 & 238 & 43 & 8 & 28 & 0 & 0 \\
\hline Arcostaphylos-alvar & $\mathrm{LL}$ & 6 & 37 & 24 & 4 & 0 & 0 & 0 \\
\hline Sesleria-alvar & LU & 5 & 0 & 0 & 0 & 0 & 0 & 0 \\
\hline Myrtillus & MS & 4 & 8317 & 968 & 1161 & 165 & 47 & 94 \\
\hline Aegopodium & ND & 1 & 24 & 3900 & 6560 & 2966 & 662 & 2176 \\
\hline Equisetum & OS & 4 & 0 & 0 & 0 & 0 & 0 & 0 \\
\hline Rhodococcum & $\mathrm{PH}$ & 4 & 19332 & 449 & 686 & 6 & 13 & 6 \\
\hline Dryopteris & SJ & 2 & 31 & 268 & 49 & 0 & 0 & 9 \\
\hline Hepatica & SL & 2 & 676 & 3299 & 608 & 107 & 0 & 323 \\
\hline Cladonia & SM & 6 & 11490 & 53 & 65 & 0 & 0 & 0 \\
\hline Vaccinium uliginosum & SN & 6 & 811 & 3 & 62 & 3 & 0 & 0 \\
\hline Carex-Filipendula & TA & 3 & 5 & 347 & 322 & 131 & 96 & 0 \\
\hline Carex & TR & 4 & 116 & 59 & 2029 & 25 & 170 & 26 \\
\hline Total / Kokku & & & 56881 & 23317 & 18777 & 4380 & 2287 & 3170 \\
\hline
\end{tabular}

and the measured diameters from the sample plots data were combined into a single file for further analysis. As the measurement interval of the sample plots was not always exactly 5 years, a linear seasonal correction with a fixed vegetation period length ( $\sim 90$ days, from the beginning of June to the end of August) was applied to adjust actual measurement results for 5 -year periods. The tree diameters were transformed into tree basal areas and prediction bias (observed minus predicted values) was calculated. Also, additional stand level information was included from the sample plots dataset. Trees that had died in the measurement period or were predicted to die by the mortality model in MOTTI were not included in the analysis.

Preliminary model evaluation was carried out by comparing predicted and observed tree basal areas. Also, a visual analysis of residual plots was performed in order to examine the model biases. Vanclay and Skovsgaard (1997) noted that plotting residuals is one of the most efficient ways to examine model performance. However, they emphasize that evaluation is a complex issue comprising a number of interrelated steps that give little information when separated. Data for each tree species was evaluated separately and the effects of different site types were analyzed. Bias of tree basal area was plotted against several variables including stand age, tree diameter, relative tree diameter, mean stand diameter, stand basal area, relative stand density, site index and site type, dominant height and temperature sum. 
After initial visual analysis, individual-tree level models for bias of predicted basal area were fitted to the data. This was done separately for all main species: Scots pine (Pinus sylvestris L.), Norway spruce (Picea abies (L.) H.Karst.), Silver birch (Betula pendula Roth), Common aspen (Populus tremula L.), Common alder (Alnus glutinosa (L.) Gaertn.) and Gray alder (Alnus incana (L.) Moench). Linear models (multiple linear regression / analysis of covariance) containing both tree and stand level variables turned out to be sufficient to describe a reasonable part of the growth model bias. Also, bias plots (both absolute and relative) were created to evaluate the performance of the bias models. These plots present bias against the same variables as were used in the Finnish calibration procedure (e.g. Fig. 12 in Hynynen et al., 2002).

The independent variables tested for model inclusion were: tree diameter $\left(D_{B H}\right)$, relative tree diameter $\left(D_{B H} / D\right)$, quadratic mean stand diameter $(D)$, stand basal area $(B A)$, relative stand density $(R D$, calculated according to Sims et al. 2009, Eq. 13) and site type (ST, see Table 1 for level coding). In addition, inclusion of some other variables, e.g. dominant height and mean stand diameter weighted by basal area were tested, but they failed to improve the predictive ability of the models. The predictors used can be grouped into four categories representing stand development phase $(D)$, stand level competition $(B A, R D)$, tree size $\left(D_{B H}\right)$ and tree level competition $\left(D_{B H} / D\right)$. The variables remained in the final models if significant $(p$-value $<0.05)$. The general model form was similar for all species; main differences are in the number of variables used and the reference level of the variable for site type. The reference levels of the site type variable for each species were chosen on the basis of the number of observations and mean prediction bias; the site type with the lowest mean prediction bias and a sufficient number of observations was selected.

\section{Results}

The basal area prediction bias models for the species included in the study are presented in Table 2 and Table 3. All models that were constructed contain site type as a factor variable. Mean stand diameter was not included in any of the models since it failed to improve model performance at a statistically significant level. Initial tree size was used for all species whereas relative tree size was used for Norway spruce, Silver birch and Common aspen. Relative stand density showed a significant relationship for Scots pine, Silver birch, Common aspen and Grey alder. Initial stand basal area displayed an effect only for Scots pine, Silver birch and Common aspen. Fig. 2 to Fig. 8 show the smoothed lines of residual biases (observed values minus predicted) of the growth models in respect to key variables when applied on Estonian data without and with the bias models applied.

\section{Scots pine}

Myrtillus was chosen as the reference level for the site type variable in the model for Scots pine since it showed little mean prediction bias and has a high number of observations. The number of levels was reduced by grouping together levels that had similar estimates and/or were not significant. This resulted in 10 groups of site types for the Scots pine model. However, no tradeoffs in model performance were allowed. The model is able to describe approximately 40 percent of the variation in prediction bias $\left(R^{2}=0.403\right)$ with a residual standard error $(R S E)$ of $0.00243 \mathrm{~m}^{2}$ per 5 -year period (Table 3). According to the variables used in the model, bias seems to be related mainly to stand level competition and individual tree size. This can be seen on the bias plots for tree size and stand development phase (Fig. 2 to Fig. 3 and Fig. 5) as well.

\section{Norway spruce}

The bias model for Norway spruce has slightly lower explanatory power than the model 


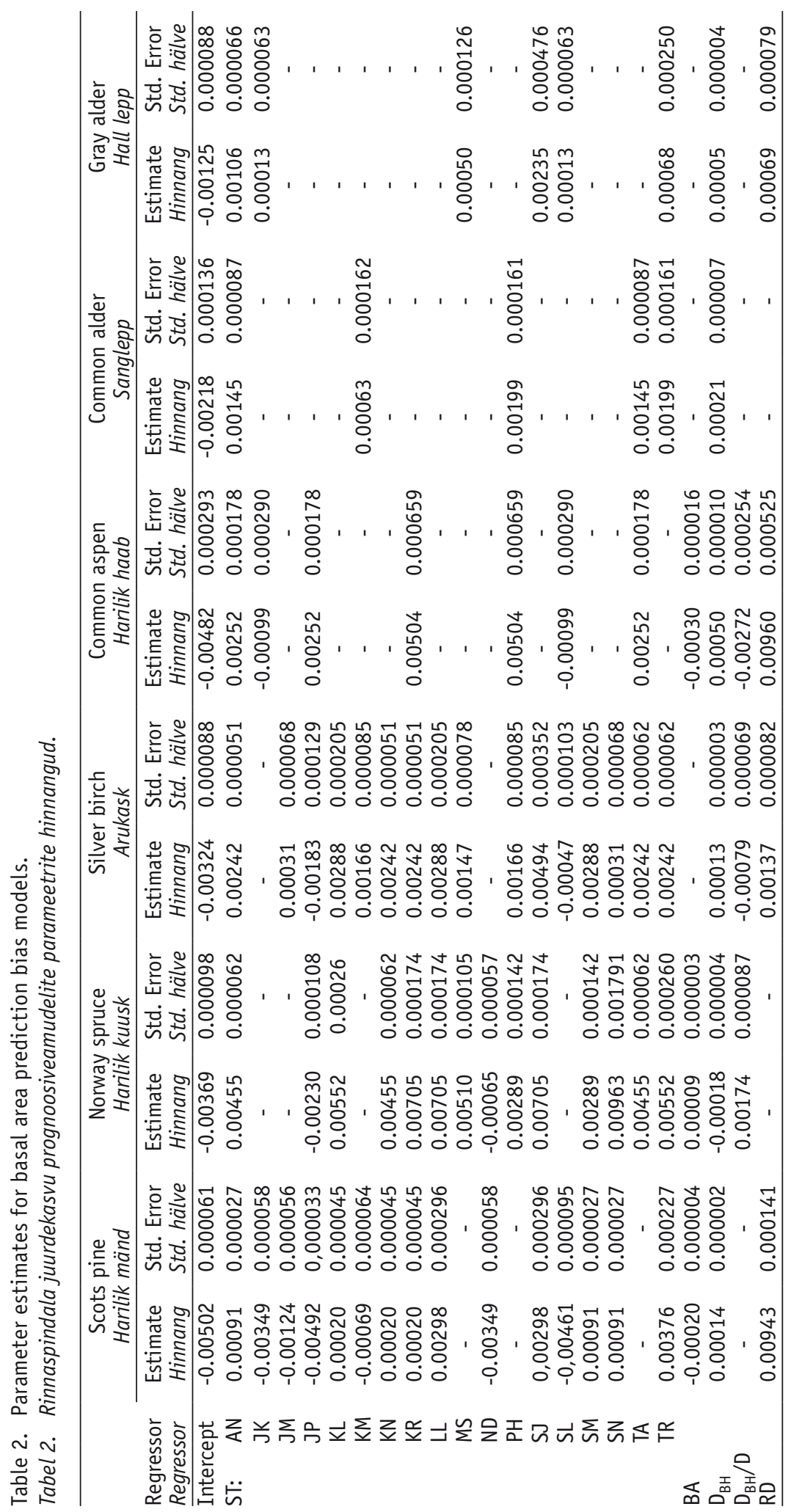




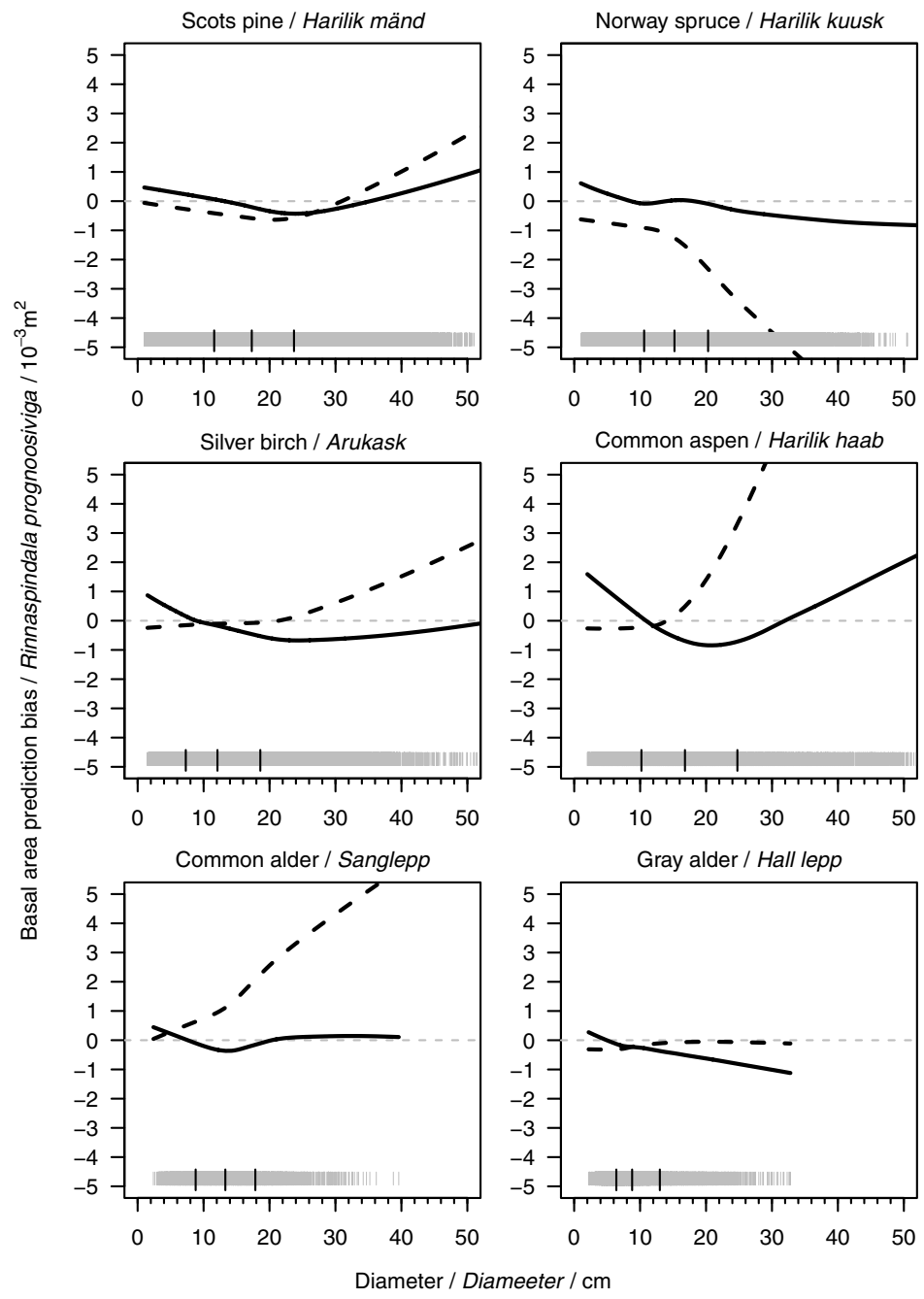

Figure 2. Absolute biases of the basal area growth models in respect to tree diameter. Dashed line - Estonian data, solid line - Estonian data with bias model applied. Grey "rug" shows observations, black ticks are quartiles $(25 \%, 50 \%, 75 \%)$.

Joonis 2. Rinnaspindala juurdekasvu veamudelite prognoosivea sõltuvus puu diameetrist. Katkendjoon näitab prognoosiviga Eesti andmetel, pidev joon näitab prognoosiviga pärast veamudeli rakendamist. Hallide joonte kogum jooniste allservas näitab vaatlusi, mustad kriipsud selle peal tähistavad kvartiile (25\%, $50 \%, 75 \%)$.

Table 3. Fit statistics for basal area prediction bias models.

Tabel 3. Rinnaspindala juurdekasvu prognoosiveamudelite statistikud.

\begin{tabular}{|c|c|c|c|c|c|c|}
\hline ts & & Nor & Silv & Comr & Common alde & Gray a \\
\hline Stat & änd & Harilik kuu & Arukask & Harilik haab & Sanglepp & Hall lepp \\
\hline $\mathrm{R}^{2}$ / determinatsioonikordaja & 0.403 & 0.374 & 0.256 & 0.544 & 0.330 & 0.146 \\
\hline RSE / Jääkstandardhälve & 0.0 & 0.0 & 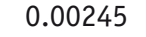 & 0. & 0. & 0.0 \\
\hline No. of obs./ Vaatluste arv & 568 & 23317 & 18 & 4379 & $22 \varepsilon$ & 3161 \\
\hline $\mathrm{F}$ & 32 & 1266 & 5 & 748 & 283 & 78 \\
\hline p-value / $p$-väärtus & $<0.0001$ & $<0.0001$ & $<0.0001$ & $<0.0001$ & $<0.0001$ & $<0.0001$ \\
\hline
\end{tabular}




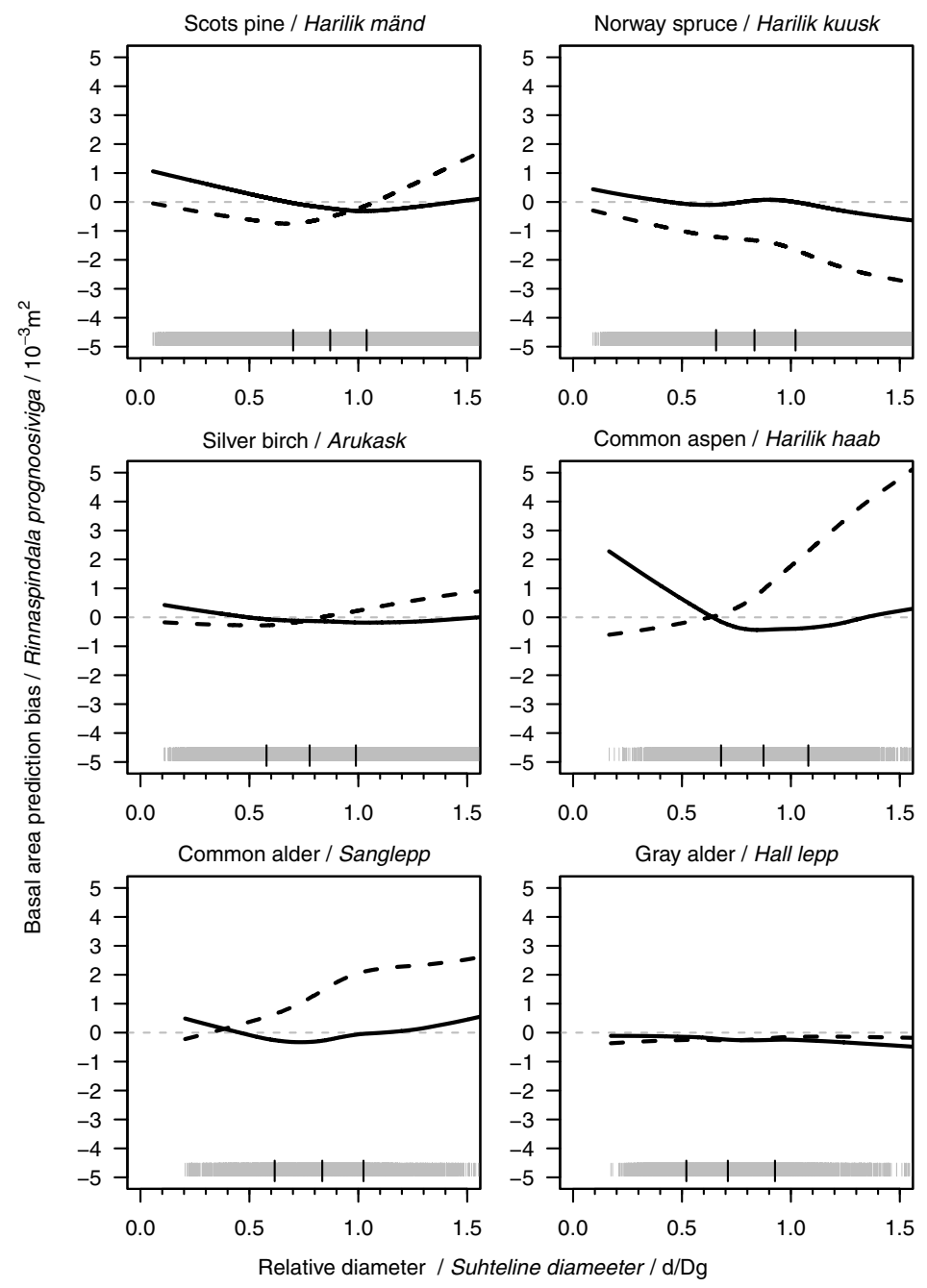

Figure 3. Absolute biases of the basal area growth models in respect to relative tree size. Dashed line - Estonian data, solid line - Estonian data with bias model applied. Grey "rug" shows observations, black ticks are quartiles $(25 \%, 50 \%, 75 \%)$.

Joonis 3. Rinnaspindala juurdekasvu veamudelite prognoosivea sõltuvus suhtelisest puu diameetrist. Katkendjoon näitab prognoosiviga Eesti andmetel, pidev joon näitab prognoosiviga pärast veamudeli rakendamist. Hallide joonte kogum jooniste allservas näitab vaatlusi, mustad kriipsud selle peal tähistavad kvartiile (25\%, 50\%, 75\%).

for Scots pine. The coefficient of determination $\left(R^{2}\right)$ is almost 3 percentage points smaller and the residual standard error is considerably bigger (Table 3). However, it should be taken into account that the number of observations is more than two times lower. Also, relative stand density was not included since it failed to improve model accu- racy. On the other hand, relative tree size turned out to have a significant effect indicating that tree level competition is biased. Regarding the site type variable, Oxalis was set as the reference site. It was possible to narrow down the number of levels of the site type variable to nine groups without causing a loss in model performance. The 


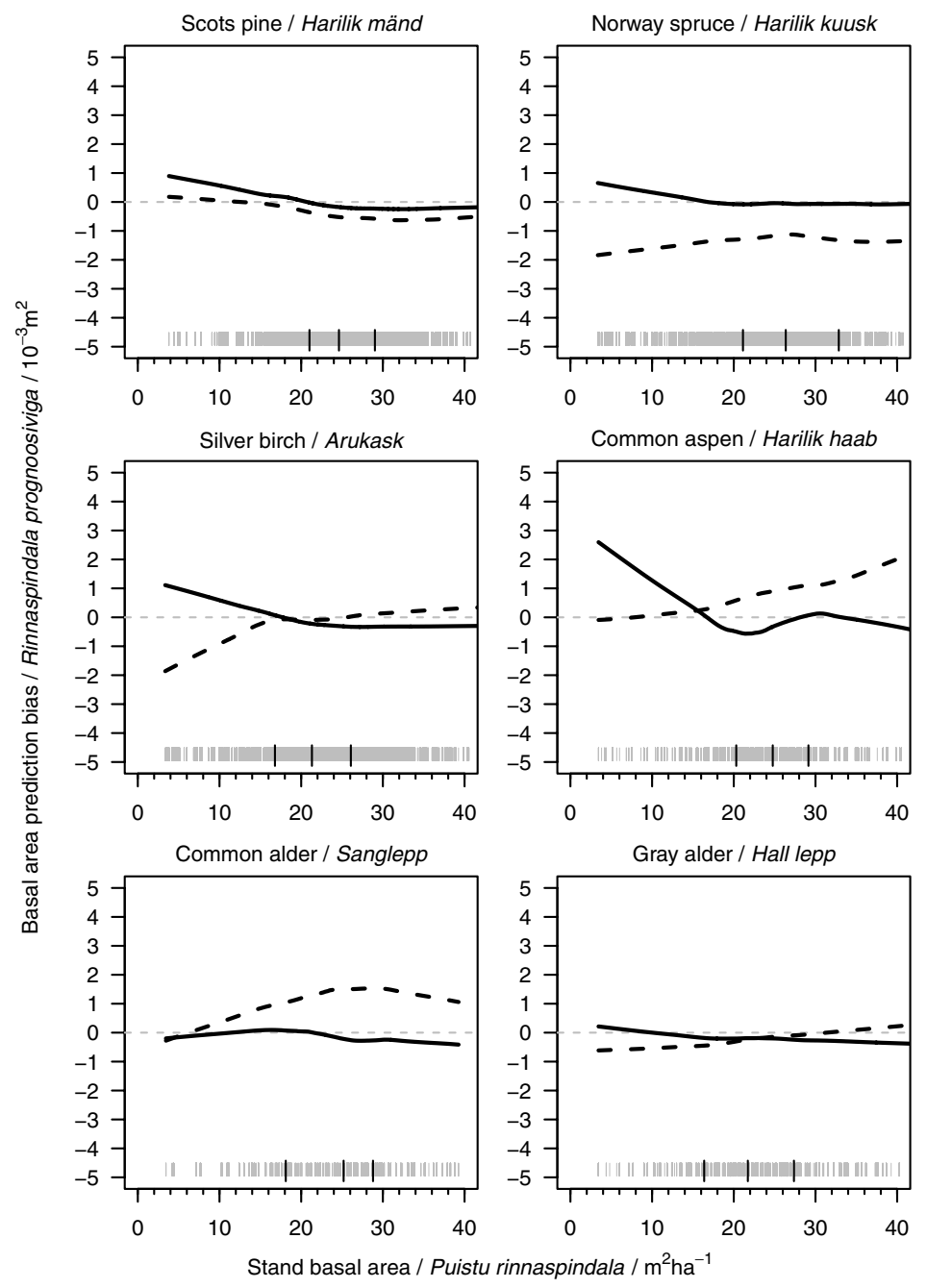

Figure 4. Absolute biases of the basal area growth models in respect to stand basal area. Dashed line - Estonian data, solid line - Estonian data with bias model applied. Grey "rug" shows observations, black ticks are quartiles $(25 \%, 50 \%, 75 \%)$.

Joonis 4. Rinnaspindala juurdekasvu veamudelite prognoosivea sõltuvus puistu rinnaspindalast. Katkendjoon näitab prognoosiviga Eesti andmetel, pidev joon näitab prognoosiviga pärast veamudeli rakendamist. Hallide joonte kogum jooniste allservas näitab vaatlusi, mustad kriipsud selle peal tähistavad kvartiile (25\%, 50\%, 75\%).

diagnostic plots (Fig. 2 to Fig. 8) show that basal area growth is mostly overpredicted for spruce; applying the bias model removes this negative trend and improves prediction accuracy considerably.

\section{Silver birch}

Table 2 shows the prediction bias model for
Silver birch. It contains regressors for treeand stand-level competition, tree size and has ten levels for different site type groups (reference level Aegopodium). Nevertheless, model performance is rather low, explaining only a quarter $\left(R^{2}=0.256\right)$ of the variation in data. On the other hand, RSE is of the same magnitude as of the model 


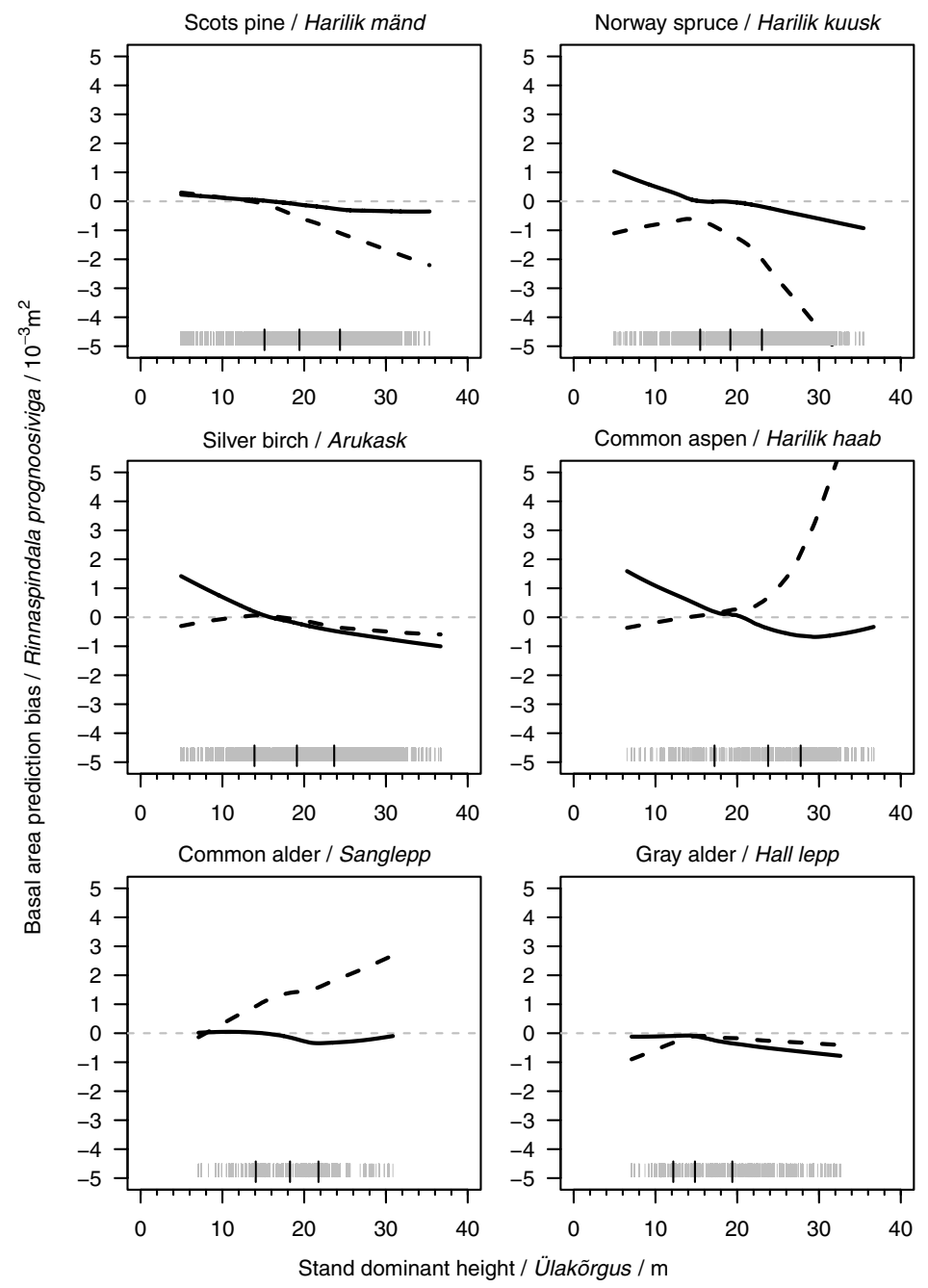

Figure 5. Absolute biases of the basal area growth models in respect to stand dominant height. Dashed line - Estonian data, solid line - Estonian data with bias model applied. Grey "rug" shows observations, black ticks are quartiles $(25 \%, 50 \%, 75 \%)$.

Joonis 5. Rinnaspindala juurdekasvu veamudelite prognoosivea sõltuvus puistu ülakõrgusest. Katkendjoon näitab prognoosiviga Eesti andmetel, pidev joon näitab prognoosiviga pärast veamudeli rakendamist. Hallide joonte kogum jooniste allservas näitab vaatlusi, mustad kriipsud selle peal tähistavad kvartiile (25\%, $50 \%, 75 \%)$.

for Sots pine, which has over three times more observations. Therefore, the basal area growth model for birch seems to be well suited for Estonian conditions. The bias plots show considerable improvement in model performance only in respect to tree size (Fig. 2) and fertility class (Fig. 7).

\section{Common aspen}

The model for Common aspen shows the best goodness of fit (Table 3), indicating the strongest prediction bias of the species included in the evaluation. The biased model behavior is clearly visible on the diagnostic plots (Fig. 2 to Fig. 8) as well. Bias 


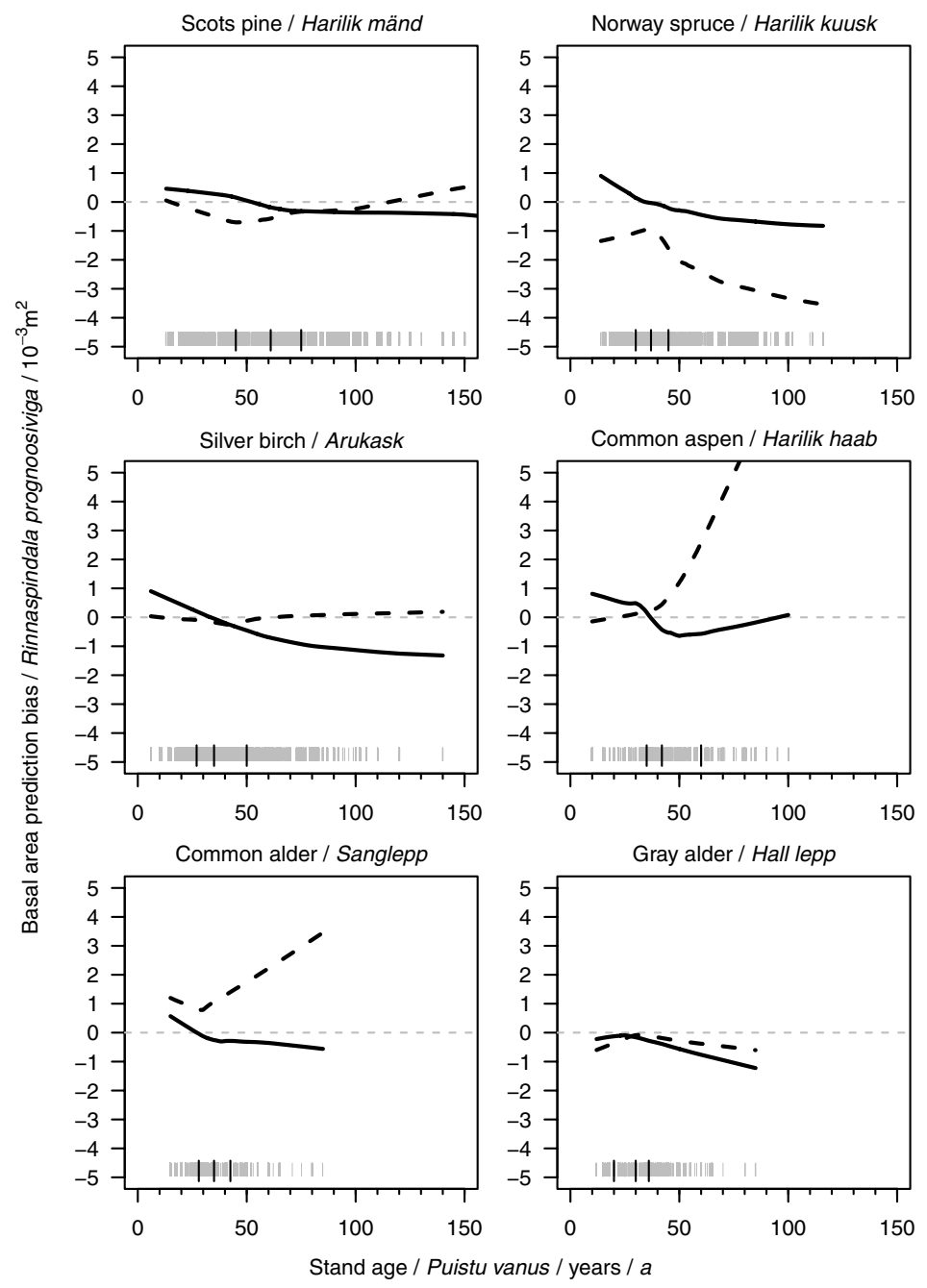

Figure 6. Absolute biases of the basal area growth models in respect to stand age. Dashed line - Estonian data, solid line - Estonian data with bias model applied. Grey "rug" shows observations, black ticks are quartiles $(25 \%, 50 \%, 75 \%)$.

Joonis 6. Rinnaspindala juurdekasvu veamudelite prognoosivea sõltuvus puistu vanusest. Katkendjoon näitab prognoosiviga Eesti andmetel, pidev joon näitab prognoosiviga pärast veamudeli rakendamist. Hallide joonte kogum jooniste allservas näitab vaatlusi, mustad kriipsud selle peal tähistavad kvartiile (25\%, $50 \%, 75 \%)$.

is related to individual tree size and both tree- and stand-level competition; however, the differences between site types are smaller since it was possible to reduce the number of levels of the variable to four. On the other hand, the number of site types where aspen was present is also smaller.
The reference level of the site type variable was set Aegopodium which is also the main type where aspen naturally occurs. Although the bias model for aspen shows the best model fit, bias is still present even after applying the bias correction (Fig. 2 to Fig. 8). 


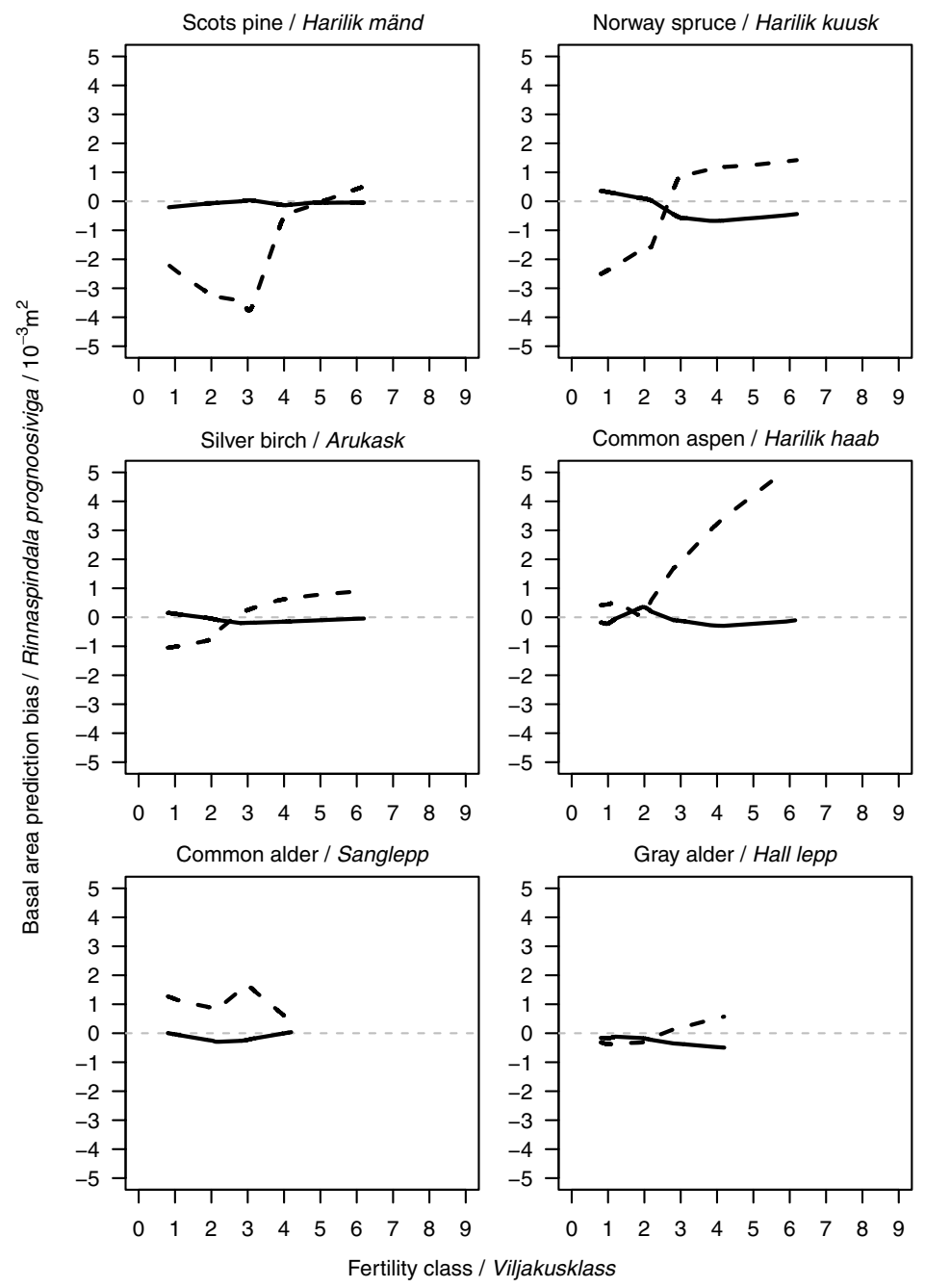

Figure 7. Absolute biases of the basal area growth models in respect to fertility classes. Dashed line - Estonian data, solid line - Estonian data with bias model applied.

Joonis 7. Rinnaspindala juurdekasvu veamudelite prognoosivea sõltuvus kasvukoha viljakusklassist. Katkendjoon näitab prognoosiviga Eesti andmetel, pidev joon näitab prognoosiviga pärast veamudeli rakendamist.

\section{Common alder}

Validation of the basal area growth prediction for Common alder resulted in the bias model described in Table 2. It uses the lowest number of explanatory variables and has only four groups of site types. Also, the dataset used for modeling has the smallest number of observations of the tree species included in this study. The ref- erence site type was set to Aegopodium one of the most fertile site types in Estonia. Competition seems to have no effect on the bias since the model contains only variables reflecting tree size and site fertility. The performance of the model is mediocre; it is able to describe approximately $1 / 3$ of the variation in predicted basal area growth. However, the plots for absolute prediction 


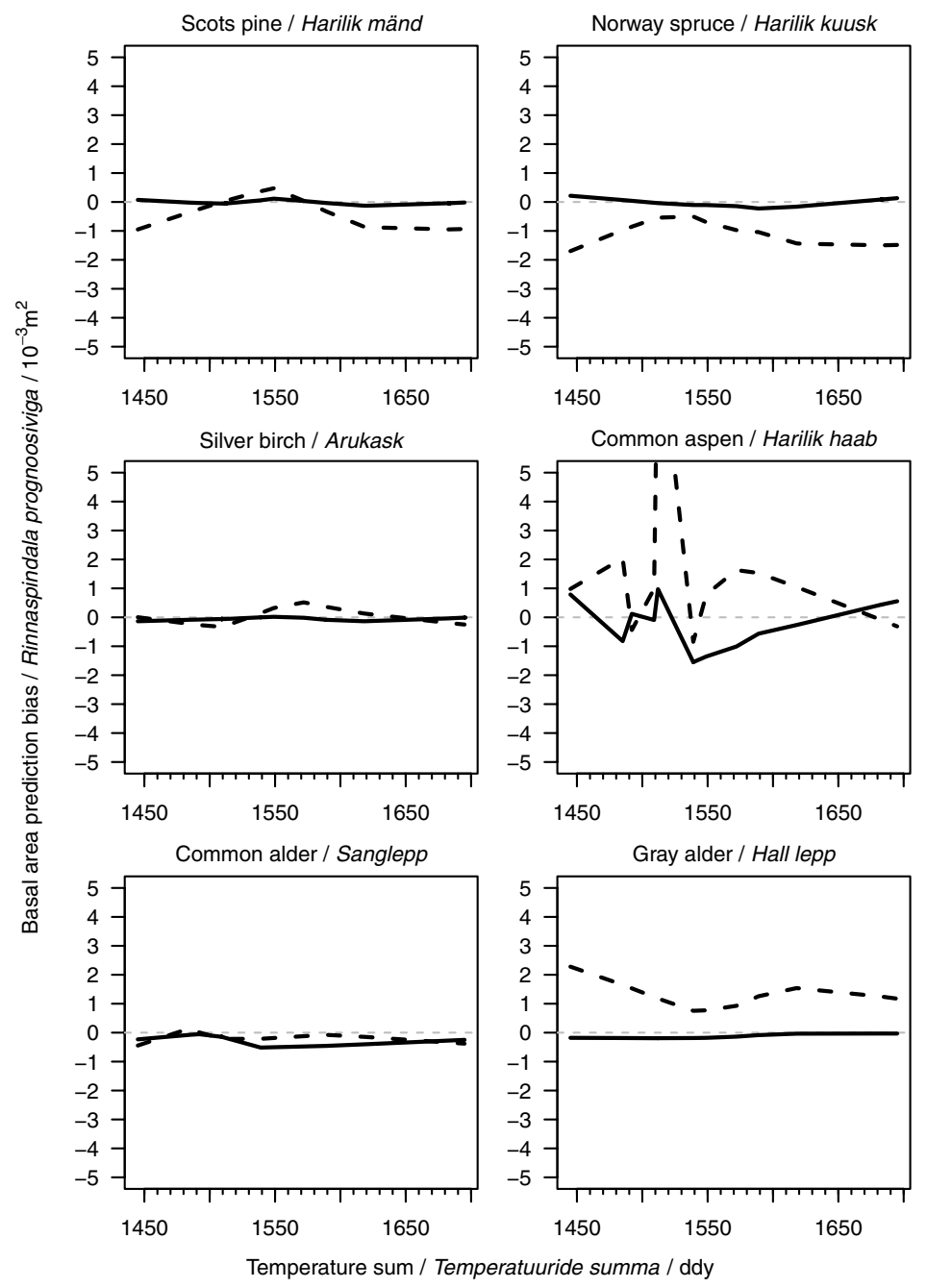

Figure. 8. Absolute biases of the basal area growth models in respect to annual temperature sum. Dashed line - Estonian data, solid line - Estonian data with bias model applied.

Joonis 8. Rinnaspindala juurdekasvu veamudelite prognoosivea sõltuvus aktiivsete temperatuuride summast. Katkendjoon näitab prognoosiviga Eesti andmetel, pidev joon näitab prognoosiviga pärast veamudeli rakendamist.

bias (Fig. 2 to Fig. 8) show that the bias model effectively reduces the prediction bias of the basal area growth model.

\section{Gray alder}

Gray alder seems to show the poorest model fit; the coefficient of determination is only 0.146. The model (Table 2) has six levels of site types but excludes tree-level competition.
Aegopodium was selected as the reference site type similarly to the other deciduous species in this study. Although the sample size was quite modest, Gray alder seems to be the species for which basal area growth is predicted most accurately. The bias plots (Fig. 2 to Fig. 8) illustrate this quite well, only the temperature sum variable (Fig. 8) shows improved performance when the bias model is applied. 


\section{Discussion and conclusions}

The models in MOTTI were evaluated and calibrated with Finnish NFI8 data before they were implemented into the system. The original idea was to calibrate the models using only site and climate variables this would have allowed to maintain the initial growth dynamics of the models. The procedure and results are described in detail by Hynynen et al. (2002). Since our objective was only to test the models and not to calibrate them at the same time, the method of constructing bias models is somewhat different. However, the evaluation part was carried out in a similar manner.

The basal area growth models in MOTTI use only mean annual effective temperature sum (threshold $>+5{ }^{\circ} \mathrm{C}$ ) to describe climate and geographical location, other variables such as altitude, sea and lake area indices are used only in the bias models. In our case, the bias models included variables describing site type, tree size and competition at both tree and stand level, but climate and geographical location remain unspecified. Temperature and location were neglected because the variability is much smaller in Estonia (from 1445 to 1695 degree-days in Estonia vs. 493 to 1353 ddy in Finland). However, they were used in the growth predictions themselves. Sea and lake indices were calculated for each plot but annual temperature sum was set at a fixed amount of $1327 \mathrm{ddy}$ (corresponding value for Vantaa, South Finland) for all plots. Actual ddy values were only used to plot the bias graphs.

The bias models constructed for the basal area growth model reveal that there are significant relationships between prediction bias and the variables tested (Table 2). Hence, it is possible to reduce the prediction bias by performing a calibration of the model. Although the bias models were fitted using stand variables that are calculated according to Estonian practice (mean stand diameter and rela- tive stand density), the models are able to describe approximately 15 to 55 percent of the variation in prediction bias. According to the output of the basal area growth models, Gray alder and Silver birch show the least biased results whereas Common aspen has the highest bias level. Scots pine and Norway spruce indicate mediocre results, the latter being mostly overestimated. The high bias level for aspen could be explained by the fact that aspen is mostly represented as admixture species in the Estonian dataset. The overprediction of spruce might be due to the overall poor health state of Estonian spruce stands - 1/3 of the spruce stands are classified as damaged stands (mainly debarking by moose and Heterobasidion root rot) according to NFI data (Adermann, 2009). When plotting relative biases against the same variables that were used in the Finnish calibration procedure, bias is reduced most with respect to site type, stand age and dominant height. Tree size and competition (relative tree size and stand basal area) still show biased trends even after applying the bias reduction models. This is somewhat unexpected since tree size and competition factors were included in the bias models, although calculated according to Estonian specification. This finding may be explained by looking at the set of variables included in models for bias. In those models, no variables referring to stage of stand development were included. On the other hand, it is known that tree size (on the average) is correlated with variables referring to the stage of stand development, such as stand dominant height. Being so, it is possible that actual impact of stand development on the bias is reflected in the variables referring to tree size. However, it requires further studies to address this issue more thoroughly. One possible option to get a better fit for our bias models is to evaluate uncalibrated model predictions i.e. to turn off the Finnish bias models in MOTTI. Also, longer simulations and data from thinning experiments are required to 
assess the potential effects of management on stand dynamics.

In general, performance of the MOTTI basal area growth model is fair; no serious structural flaws could be detected. Considering that the model was applied outside its initial input range, the results suggest that the description of stand dynamics and basic structure of growth prediction of MOTTI system could be adapted to Estonian conditions. However, it requires more research efforts to develop calibration procedure resulting in a model variant applicable to serve as a tool in decision support for practical forest management planning purposes in Estonia. This includes the evaluation (and calibration if necessary) of all other models used in MOTTI system.

Acknowledgements. This study was supported by Estonian Environmental Investment Centre, State Forest Management Centre and The Ministry of Education and Research (projects SF0170014s08 and ETF8890). The Estonian Meteorological and Hydrological Institute provided climate data.

\section{References}

Adermann, V. (ed.). 2009. Eesti Metsad 2008. (Estonian Forests 2008). Tallinn, Metsakaitse- ja Metsauuenduskeskus. 134 pp. (In Estonian).

Cieszewski, C.J., Bella, I.E. 1989. Polymorphic height and site index curves for lodgepole pine in Alberta. Canadian Journal of Forest Research, 19, 1151-1160.

Eesti metsade statistilise inventeerimise metoodika. (Methodology for Estonian National Forest Inventory). 2000. Käsikiri. (Manuscript). Metsaekspert OÜ. Tartu. 57 pp. (In Estonian).

Gustavsen, H.G., Roiko-Jokela, P., Varmola, M. 1988. Kivennäismaiden talousmetsien pysyvät (INKA ja TINKA) kokeet: suunnitelmat, mittausmenetelmät ja aineistojen rakenteet. (Permanent experiments (TINKA and INKA) in commercial forests on mineral soil sites. Plans, measurements and data structure). Metsäntutkimuslaitoksen tiedonantoja, 292, 212 p. (In Finnish).

Haller, B. 1932. Uurimusi mustlepa (Alnus glutinosa Gaertn.) kasvukäigust. (Studies on the growth response of black alder). Tartu Ülikooli Metsaosakonna toimetused nr. 21. (In Estonian with
German summary).

Hägglund, B. 1981. Forecasting growth and yield in established forests. Swedish University of Agricultural. Sciences, Department of Forest Survey, Report 31.

Henno, O. 1959. Paremaboniteediliste kaasikute kasvukäik Eesti NSV-s. (Yield tables of silver birch stands growing on fertile site types in Estonian SSR). Eesti Põllumajandusakadeemia teaduslike tööde kogumik, 11, 50-58. (In Estonian with summaries in German and Russian).

Henno, O. 1965. Kase standardtabel. (Yield table for Silver birch). Eesti Põllumajandusakadeemia teaduslike tööde kogumik, 41, 114-119. (In Estonian).

Hynynen, J. 1993. Self-thinning models for even-aged stands of Pinus sylvestris, Picea abies and Betula pendula. Scandinavian Journal of Forest Research, 8(3), 326-336.

Hynynen, J., Ojansuu, R., Hökkä, H., Siipilehto, J., Salminen, H., Haapala, P. 2002. Models for predicting stand development in MELA System. Metsäntutkimuslaitoksen Tiedonantoja, 835, 116 p.

Hynynen, J., Ahtikoski, A., Siitonen, J., Sievänen, R., Liski, J. 2005. Applying the MOTTI simulator to analyse the effect of alternative management schedules on timber and non-timber production. Forest Ecology and Management, 207, 5-18.

Jõgiste, K. 1998. Productivity of mixed stand of Norway spruce and birch affected by population dynamics: a model analysis, Ecological Modelling, 106, 77-91.

Kangur, A., Sims, A., Jõgiste, K., Kiviste, A., Korjus ,H., Gadow, K. von. 2007. Comparative modeling of stand development in Scots pine dominated forests in Estonia. Forest Ecology and Management, 250, 109-118.

Karoles, K., Õunap, H., Pilt, E., Terasmaa, T., Kivits, H. 2000. Forest condition in Estonia in 1988-99, defoliation and forest damages on Level 1 sample points. Forestry Studies / Metsandulikud Uurimused, 33, 209-216.

Kasesalu, H. 1969. Nõmmemännikute kasvukäigust. (About the growth of pine stands on heath sites). Metsanduslikud Uurimised, 7, 128-142. (In Estonian).

Kiviste, A. 1995. Eesti riigimetsa puistute kõrguse, diameetri ja tagavara sõltuvus puistu vanusest ja kasvukohatingimustest 1984.-1993. a. metsakorralduse takseerkirjelduste andmeil. (The effects of stand age and site on stand height, diameter and volume in Estonian state owned forests according to forest inventory data from 1984-1993). Eesti Põllumajandusülikooli teadustööde kogumik, 181, 132-148. (In Estonian).

Kiviste, A. 1997. Eesti riigimetsa puistute kõrguse, diameetri ja tagavara vanuseridade diferentsmudel 1984-1993. a. metsakorralduse takseerkirjelduste andmeil. (Difference equations of stand height, diameter and volume depending on stand age 
and site factors for Estonian state forests). Eesti Põllumajandusülikooli teadustööde kogumik, 189, 63-75. (In Estonian).

Kiviste, A. 1999a. Eesti puistute kasvumudelitest. (About the Estonian forest growth models). Pidev metsakorraldus, EPMÜ Metsandusteaduskonna toimetised 32: 28-36. (In Estonian).

Kiviste, A. 1999b. Site index change in the 1950s-1990s according to Estonian forest inventory data. - Karjalainen, T., Spiecker, H., Laroussinie, O. (eds.). Causes and Consequences of Accelerating Tree Growth in Europe. EFI Proceedings, 27, 87-100.

Kiviste, A., Hordo, M. 2002. Eesti metsa kasvukäigu püsiproovitükkide võrgustik (Network of permanent forest growth plots in Estonia). Forestry Studies / Metsanduslikud Uurimused, 37, 43-58. (In Estonian with English summary).

Kiviste, A., Nilson, A., Hordo, M., Merenäkk, M, 2003. Diameter distribution models and height-diameter equations for Estonian forests. - Amaro, A., Reed, D., Soares, P. (eds.). Modelling forest systems. CAB International, 169-179.

Krigul, T. 1969. Metsataksaatori teatmik (Forest surveyor's handbook). Tartu, Eesti Põllumajandusakadeemia. (In Estonian).

Kull, K., Kull, O. 1989. Dynamic modelling of tree growth. Academy of Sciences of the Estonian SSR. Institute of Zoology and Botany. 232 p. (In Russian with English summary).

Kuusela, K., Salminen, S. 1969. The 5th National Forest Inventory in Finland. General design, instructions for field work and data processing. Communicationes Instituti Forestalis Fenniae, 69(4), 1-72.

Lõhmus, E. 2006. Eesti metsakasvukohatüübid. (Estonian Forest Site Types). Tartu, Eesti Loodusfoto. 80 p. (In Estonian).

Muiste, L. 1959. Uurimusi männi kultuurpuistute kasvukäigust Kagu-Eesti metsamajandites. (Studies on the growth of artificially regenerated pine stands in South-East Estonia). Eesti Põllumajandusakadeemia teaduslike tööde kogumik, 6, 196-206. (In Estonian with Russian summary).
Nilson, A. 2005. Puistute kõrguse kasvu üldistus boniteerimiseks sobivate diferentsmudelitena. (Generalization of height growth as difference equations fit for estimating the site index of stands). Forestry Studies / Metsanduslikud Uurimused, 43, 173-184. (In Estonian with English summary).

Oja, T., Arp, P.A. 1997. A forest soil vegetation atmosphere model (ForSVA). II: Application to northern tolerant hardwoods. Ecological Modelling, 95(2-3), 225-247.

Reim, P. 1930. Juurdekasvu meetod toogitabelite valmistamisel ja toogitabelid Eesti männimetsadele. (Increment method for composing yield tables and yield tables for pine stands in Estonia). Eesti Metsanduse Aastaraamat IV. (In Estonian with German summary).

Salminen, H., Lehtonen, M. \& Hynynen, J. 2005. Reusing legacy FORTRAN in the MOTTI growth and yield simulator. Computers and Electronics in Agriculture, 49(1), 103-113.

Siitonen, M. 1993. Experiences in the Use of Forest Management Planning Models. Silva Fennica, 27(2), 167-178.

Sims, A., Kiviste, A., Hordo, M., Laarmann, D., Gadow, K. von. 2009. Estimating Tree Survival: a Study based on the Estonian Forest Research Plots Network. Annales Botanici Fennici, 46, 336-352.

Söderberg, U. 1986. Functions for forecasting of timber yields. Increment and form height for individual trees of native species in Sweden. Swedish University of Agricultural Sciences, Section of Forest Mensuration and Management, Report No. 14. 251 pp. (In Swedish with English summary).

Tappo, E. 1982. Eesti NSV puistute keskmised takseertunnused puistu enamuspuuliigi, boniteedi ja vanuse järgi. (Mean stand parameters by main species, site class and age in the Estonian SSR). Eesti Metsakorralduskeskus. 72 p. (In Estonian).

Vanclay, J.K., Skovsgaard, J.P. 1997. Evaluating forest growth models. Ecological Modelling, 98, 1-12.

\title{
Soome puistukasvusimulaatori MOTTI rinnaspindala juurdekasvu- mudelite prognoositäpsuse hindamine Eesti metsa kasvukäigu püsiproovitükkide võrgustiku mõõtmisandmete põhjal
}

\author{
Ando Lilleleht, Allan Sims, Andres Kiviste, Jari Hynynen ja Mika Lehtonen
}

\section{Kokkuvõte}

Metsade majandamine on väljunditerohke metsanduse populariseerimise tõttu muutumas üha keerulisemaks protsessiks - sageli tuleb silmitsi seista erinevate huvigruppide vastandlike nõudmistega. Sellise puistute majandamisrežiimi leidmine, mis arvestaks 
kõikide osapoolte huvidega, on kahtlemata keeruline, sest üldjuhul on praktikud erialase hariduse omandanud ajal, mil domineeris klassikaline puidutootmisele orienteeritud metsandus. Abi võib leida puistukasvusimulaatoritest, mis võimaldavad erinevaid arengustsenaariume modelleerida. Kuivõrd Eesti metsade kohta sellist tarkvara välja töötatud ei ole, on käesoleva uurimuse eesmärgiks hinnata Soomes loodud puistukasvusimulaatori MOTTI rakendatavust Eesti oludes.

MOTTI on üksikpuu-tasandil puistukasvumudelitele toetuv tarkvarapakett, mille väljaarendamisel on üheks oluliseks eesmärgiks seatud võimalus analüüsida erinevate majandamisvõtete mõju nii puidutoodangule kui ka mittepuidulistele väärtustele. Käesolevas artiklis keskendutakse eelkõige rinnaspindala juurdekasvumudelitele, millede headust hinnatakse Eesti metsa kasvukäigu püsiproovitükkide võrgustiku mõõtmisandmeid kasutades. Analüüsi jaoks kasutati ainult mineraalmaadel kasvavate puistute esimese rinde puude andmeid, sest soometsade kasvu prognoositakse MOTTIs eraldi mudelitega. Täiendavaid kitsendusi, näiteks puistute koosseisu, tekkeviisi, vanuse või täiuse suhtes valimi koostamisel ei tehtud. Andmete MOTTIsse sisestamiseks tuli juurde arvutada mitmeid uusi tunnuseid, mida Eesti metsanduse praktikas ei kasutata, näiteks proovitüki läheduses olevate veekogude pindalaindeks, samuti tuli teisendada Lõhmuse kasvukohatüübid Soomes kasutatavasse kasvukoha viljakusklasside süsteemi. Uurimuse käigus koostati puu-tasemel juurdekasvu prognoosiveamudelid peamiste majanduslikku tähtsust omavate puuliikide kohta. Ühtlasi vaadeldi vea sõltuvust erinevatest puistut kirjeldavatest tunnustest, nii kasvumudelites kasutatud muutujatest kui ka teistest tunnustest, mis teadaolevalt võiksid juurdekasvule mõju avaldada.

Tulemused näitavad, et vea suurus varieerub puuliigi ja kasvukohatüübi lõikes, samuti on eri liikide puhul mõju erinevatel tunnustel. Toetudes koostatud veamudelite statistikutele, võib väita, et hariliku haava puhul on prognoosiviga suurim, seevastu hall lepp näitab väikseimat erinevust tegelike mõõtmisandmetega. Hariliku männi juurdekasvu prognoosiviga sõltub põhiliselt puistu tasemel konkurentsist ja puu diameetrist, üldise trendina võib täheldada mõningast juurdekasvu ülehindamist. Hariliku kuuse kasv on samuti ülehinnatud, kuid oluliselt suuremas ulatuses. Veamudelis kasutatud tunnuste põhjal avaldavad kuuse prognoosiveale suurimat mõju puu- ja puistu tasemel konkurents. Arukase puhul ühtset üle- või alahindamist ei ilmne, juurdekasvumudeli ennustuse viga seostub enim puu suuruse ja puistu täiusega. Ainus puuliik, mille korral ei ole konkurentsi kirjeldavatel tunnustel mudeli prognoosiveaga usaldusväärset seost on sanglepp. Üldise tendentsina saab sanglepal täheldada küllaltki tugevat rinnaspindala juurdekasvu alahindamist, koostatud veamudeli alusel on see seotud puu diameetriga.

Kuigi MOTTI rinnaspindala juurdekasvumudelite prognoosivõimet võib Eesti andmete peal rakendades pidada üsnagi heaks, eriti arvestades, et mudelit kasutati väljaspool tema loomiseks kasutatud andmestiku piire, tuleks mudel enne praktikas kasutamise eesmärgil ülevõtmist kalibreerida kohalikul andmestikul. 